fied and can be equipped with a portable generator, $16 \mathrm{~mm}$ film-projector, slide-tape unit, public address system, and display screens-all carried in foam-lined rigidized aluminium cases and compartments for safe travel on rough roads. Diesel-powered Land Rovers have also been equipped for areas where more difficult terrain is likely to be encountered.

Besides equipping mobile education units, the Centre provides comprehensive back-up support to information centres and field conservationists working in remote areas. Most of the equipment offered has been selected as the most appropriate for educational work and then 'field tested' to prove its value and reliability in operation. Photographic and printing services are also available, and spare parts can be ordered and despatched. ICCE's staff also visit developing countries to advise both government departments and non-government organizations on the establishment and development of national conservation education programmes.

\section{Training Courses and Newsletter}

Over the years, these activities have encouraged the establishment of similar environmental resource-centres by developing countries themselves. As part of this policy, the Centre initiated an international training course for nationals of Third World countries working in environmental education. Thanks to a generous donation by the Elsa Wild Animal Appeal and support from WWF International, it was possible to establish and equip the Joy Adamson Memorial Training Room at ICCE. This part of the Centre incorporates a small library and audio-visual projection facilities as well as providing the main working area for trainees. Courses are extremely practical, begin- ning where most theoretical teaching ends. They allow trainees to develop a variety of 'real' educational resources to assist them in their work. To date, four courses have been run and fifteen trainees, mostly from African countries, have produced a wide variety of educational aids relevant to their needs-including audio-visual programmes, posters, booklets, leaflets, certificates, and also materials such as calendars and lapel badges to help with fund-raising activities.

ICCE is also involved in several other activities which are not always easy to categorize: for example, to help promote greater cooperation between conservation organizations and environmental educators working in Africa, ICCE publishes the 'Africa Link' newsletter with funding from the Elsa Wild Animal Appeal. 'Africa Link' provides information, ideas, and practical advice, on all matters relating to conservation education in Africa-training, equipment, materials, funding agencies, and so on.

Success or failure for many conservation projects will depend increasingly on highly-motivated and well-trained local personnel who understand not only the conservation problems and dilemmas of their own country but also the cultural situation in which they occur. They will need appropriate resources to carry out the work-to inform, influence, and guide. They will need educational materials, new skills in communication, and continuing practical support. This is the challenge to which ICCE is responding.

PHILIP STEELE, Deputy Director
International Centre for Conservation Education
Greenfield House
Guiting Power
Cheltenham
Gloucestershire GL54 5TZ, England, UK.
International Centre for Conservation Education Greenfleld House

Cheltenham Gloucestershire GL54 5TZ, England, UK.

\title{
Regulated Rivers
}

Since the earliest 'hydraulic' civilizations, Man has sought to understand and to control rivers in order to optimize the economic benefits from their water and adjacent floodplain lands. Early civilizations along the Indus, Nile, Hwang Ho, and Tigris-Euphrates, flourished over long periods of history by managing their land and water resources in a way that harmonized the pursuit of economic objectives with the integrity of their environment. In contrast, the recent history of river management has been dominated by technological 'achievements': large multipurpose dams, long-distance water transfers, and widespread canalization. Moreover, technology has advanced more quickly than has our knowledge of the environmental consequences!

Virtually every major river in the world is now regulated in some way. The impacts include plant and animal species extinctions, loss of special habitats, destruction of traditional fisheries, and desertification or salinization of oncefertile floodplains. Many impacts have resulted directly from river regulation, but others are caused by secondary effects associated not least with increased discharges of agricultural, domestic, and industrial, effluents.

Today, integrated land and water management giving due regard to the maintenance of ecological balance is seen as a fundamental part of sustainable development policies. Furthermore, it is recognized that, utilizing appropriate management strategies, river regulation can make a positive contribution to environmental conservation. In order to realize the benefits for Nature and natural resources, and to minimize foreseeable impacts from future river regulation schemes, river management must utilize knowledge from critical appraisals of the past and present environmental problems of river 'developments', and must adopt an anticipatory approach to those problems. One additional need is to develop improved approaches and techniques for the restoration of damaged ecosystems.

To provide a focus for research on the environmental effects of river regulation, and to advance our knowledge of management alternatives, a new journal is being established. Regulated Rivers is an international journal dedicated to the promotion of interdisciplinary research and testing that is concerned directly or indirectly with river management. The journal is devoted to the rapid publication of scientific and technical papers on biological, ecological, engineering, and geographical, aspects relating to both the developed and 'developing' worlds. Research focusing on reservoirs, drainage-basin development, wetlands, estuaries, and the near-shore coastal zone, etc., may also be included if set in the context of the regulated river system. Topics will include, for example, fishway design, reservoir release strategies, water-quality control, channel erosion and sedimentation, changes of flora and fauna, problems of health and disease, and environmental modelling.

Supported by a truly international and multidisciplinary Editorial Board, Regulated Rivers will be published quarterly, commencing Autumn 1986, by John Wiley \& Sons, Chichester, England, UK. The subscription price is $£ 65.00$ or $\$ 110.00$.

Geoffrey E. Petts, Editor-in-Chief Department of Geography University of Technology Loughborough Leicestershire LE11 $3 T U$ England, UK. 